\title{
THE BIOLOGICAL CHARACTERISTICS STUDY OF THE SPIDER, THERIDION SPINITARSE O. PICKARD-CAMBRIDGE, 1876 (ARANEAE:THERIDIIDAE) IN EGYPT
}

\author{
Naglaa F. R. Ahmad ${ }^{(1)}$ and H. M. Heikal ${ }^{(2)}$ \\ ${ }^{(1)}$ Plant Protection Research Institute, Agric. Research Center, Giza, Egypt \\ (2) Economic. Entomol. And Agric. Zool. Dept. Fac. Agric, Menoufia University \\ ${ }^{1}$ Corresponding e-mail address: naglaaahmad@gmail.com \\ Received: Apr., 19, 2016 \\ Accepted: May 7, 2016

\begin{abstract}
Theridion spinitarse was described as a new species for the first time from female by O. Pickard-Cambridge, 1876, then Knoflach, et al. (2009) re-described this species from female specimens. Spider specimens were collected from mango trees in Fayoum Governorate and from grapes at El-Sadat sector of Menoufia Governorate. Individuals of the spider were rearedand biological aspects were studied under laboratory conditions $\left(25^{\circ} \mathrm{C}\right.$ and $60-70 \%$ R.H). Individuals of this species fed every two days on second larval stage of Spodoptera littoralis (Boisduval 1833). Males and females reached maturity in the fifth spiderling stage after 67 \& 72.27 days, respectively. Adult longevity, lifespan, fecundity of female and food consumption were also studied.
\end{abstract}

Key words: Theridion spinitarse, life cycle, food consumption, spiders, Spodoptera littoralis, life history, fecundity, Theridiidae, Egypt.

\section{INTRODUCTION}

Spiders have a wide host range where they feed on insects and some other arthropods. They can play an important role in pest control. There are about 114 families, 3981 genera and 45,862 identified and described species have been in the world (Platnick, 2014).Theridiids show large areas of distribution, Theridion Walckenaer, 1805 is the type genus of Family Therididae Sundeall, 1833, as defined by Levi (1957, 1959, and 1963). Also Theridion the largest genus of the theridiids and considered as one of the largest genera amongst all spiders (Levy and Amital 1982). Theridion has more than 587 species worldwide (Platnick, 2014).T.pictum (Walckenaer) the type species of Theridion. In Egypt, there are 8 species recorded of genus Theridion: T. melanostictum O.P.-Cambridge, 1876, $T$. musivum Simon, 1873, T. nigrovariegatum Simon, 1873, T. spinitarse O.P.-Cambridge, 1876, T. varians Hahn, 1833 (El-Hennawy, 2006), T. cairoense (Wunderlich, 2011), T. incanescens Simon, 1890 and T. jordanense Levy \& Amitai, 1982 (Knoflach \& ElHennawy 2012).

Knowledge of the biological characters for different species of Theridion has been targeted by many scientists around the world. Liu Hancai et al. (2002)studied the living habit and biological character of $T$. octomacutatum, Abo-Taka et al. (2004) reared T. melanostictum Rahil (2004) studied the biological characters of $T$. spinitarse Zhuang Su et al. (2005) observed the biological characters of $T$. pinastri, Yu hong-guo et al. (2009) studied the biological characters of $T$. tepidariorum, Abd El-Azim (2014) reared Theridion melanostictum, Ahmad and Abd El- Maaboud (2014) studied the biological aspects of the spider $T$. incanescens and Sallam et al. (2015) reared $T$. jordanense.

$T$. spinitarse was first described from female specimens only collected on a low plant near Cairo by O. Pickard-Cambridge et 
al. 1876. Knoflach et al. (2009) re-described female specimens collected on Asswan, Egypt. The first description of the male was conducted by El-Hennawy \& Ahmad (In Press).

\section{MATERIALS AND METHODS Spiders rearing:}

Adult females of $T$. spinitarse, was collected from mango trees in Fayoum Governorate and from grapes at El-Sadat sector, Menoufia Governorate. Identification of the species depended on the redescription of El-Hennawy and Ahmad (2016). Specimens were reared under laboratory conditions, $25^{\circ} \mathrm{C}$ and $60-70 \%$ R.H in plastic vials ( $3 \mathrm{~cm}$ diameter $\times 5 \mathrm{~cm}$ height). Each two egg sacs were placed in one plastic vial and replicated 20 times. Hatched spiderlings were individually reared and fed every two days on second larval stage of Spodoptera littoralis (Boisduval, 1833) handled by camelhair brush.

\section{Rearing of Spodoptera littoralis:}

Laboratory strain of cotton leaf worm $S$. littoralis was obtained as egg masses and larvae from the Economic Entomology and Pesticides Department, Faculty of Agriculture, Cairo University. All stages were kept in glass jars $(20 \mathrm{~cm}$ height and $12.5 \mathrm{~cm}$ diameter) covered by muslin and cultured under room temperature. Larvae were reared on leaves of castor-oil plant, Ricinus communis (L.), which were washed in running water and dried before being placed in rearing jars. Larvae faeces were removed and $R$. communis old leaves were replaced by new ones every two days. As larvae reached the fifth larval stage, saw dust was placed in the jars to absorb any excess moisture and to allow pupation at the end of larval stage. Pupae were collected and placed in separate jars under the same conditions. The newly emerged male and female moths were allowed to mate. The rearing jars were lined with paper to provide an egg laying site and daily provided with cotton pads moistened with $10 \%$ honeybee solution for the nutrition of the adults. Egg masses laid on the paper were daily removed and transferred to clean jars according to Ahmed (2009). Second larval stage produced from these egg masses were used as a prey for the spider.

\section{RESULTS AND DISCUSSION Incubation period, sex ratio:}

Spherical light-gray egg sacs were laid, became dark gray before hatching. The incubation period was 15 days under laboratory conditions of $25^{\circ} \mathrm{C} \pm 2$ and 60 $70 \%$ R.H.

After leaving the egg-sac 40spiderlings were reared, all of them reached adult stage (18 males and 22 females). The sex ratio of adult individuals was 1: 1.2 (Male: female).

\section{Spiderlings development:}

Maturity was started at the fifth spiderling stagefor males and females (Table 1) and Fig (1-3). The obtained data were agree with (Hussein et al., 2003) \& (Sallam et al., 2010) and (Ahmad and Abd El-Maaboud, 2014) where they studied the biological aspects of Kochiura aulica and Theridion incanescens. This may be due to the convergence of size between three species also between male and femalein the same species. This reason is consistent with Foelix (2011)who reports that the number of molts depends on the ultimate body size, therefore, small spiders need only a few molts (about 5), whereas large spiders pass through about 10 molts to reach adult stage (Bonnet, 1930). The small males achieve maturity with one or two fewer molts than the larger females, but may be disagree with the results with those of Abo-Taka et al.(2004), Rahil (2004), Abd ElAzim (2014) and Sallam, et al.(2015).The duration of the different stages of $T$. Spinitarse was directly proportional to spiderlings. The shortest duration was first 
spiderling (lasted average 3 days for male and female). The longest duration was that of the fifth spiderling in males and females in spite of the last molting of the male was faster than counterpart in the female (Table 1). This compatible with Foelix (2011) who found that early nymphal stages may molt every few days but later spiderlings need several weeks to prepare for the next molt.

Total spiderlings duration was $52.00 \pm 1.55$ and $57.27 \pm 8.15$ days for males

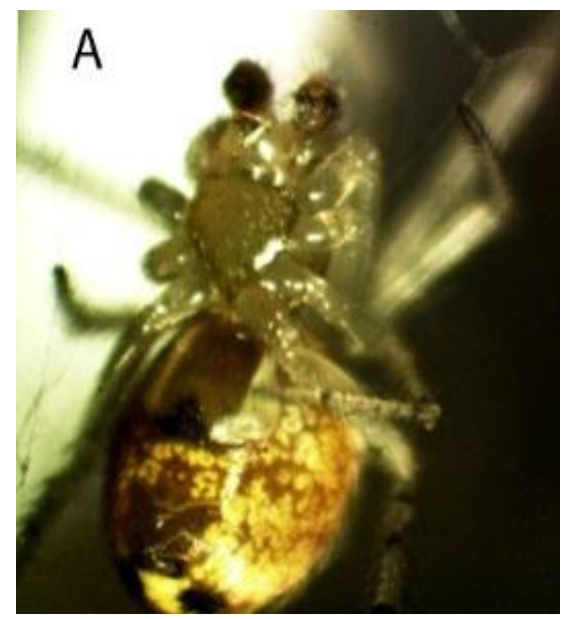

and females, respectively. Life cycle duration was $67 \pm 1.55$ and $72.27 \pm 8.15$ days for males and females, respectively.

\section{Adult longevity and Life span:}

The adult longevity was recorded as 93.17 \pm 2.93 and83.00 \pm 13.78 days for males and females, respectively.

The Life span lasted on $160.17 \pm 2.04$ and $155.27 \pm 8.88$ days for male and female, respectively.

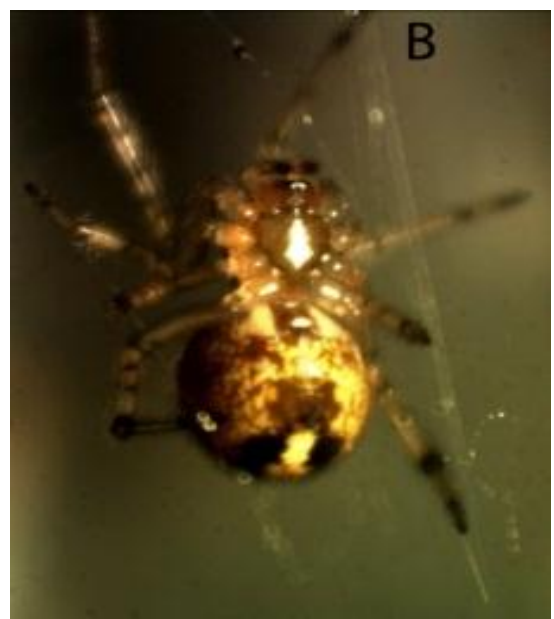

Fig. (1): Theridion spinitarse O.Pickard-Cambridge Adult. A (Male) and B(Female) ventral view.
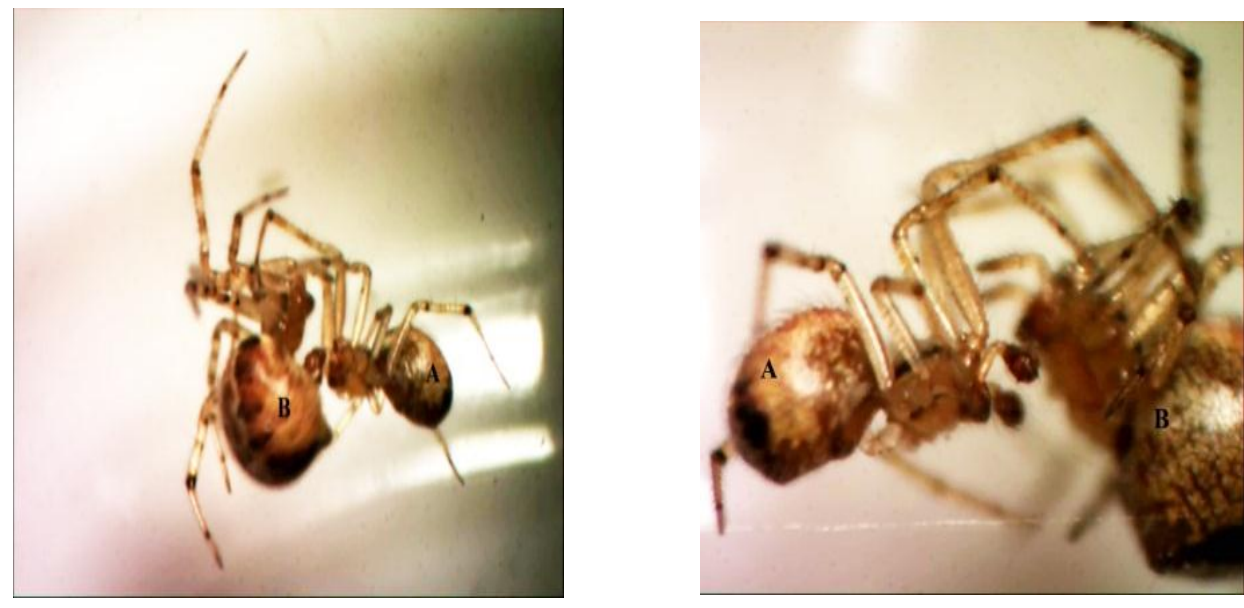

Fig. (2): Theridion spinitarse O. Pickard-Cambridge adult, A (Male) and B (Female). 

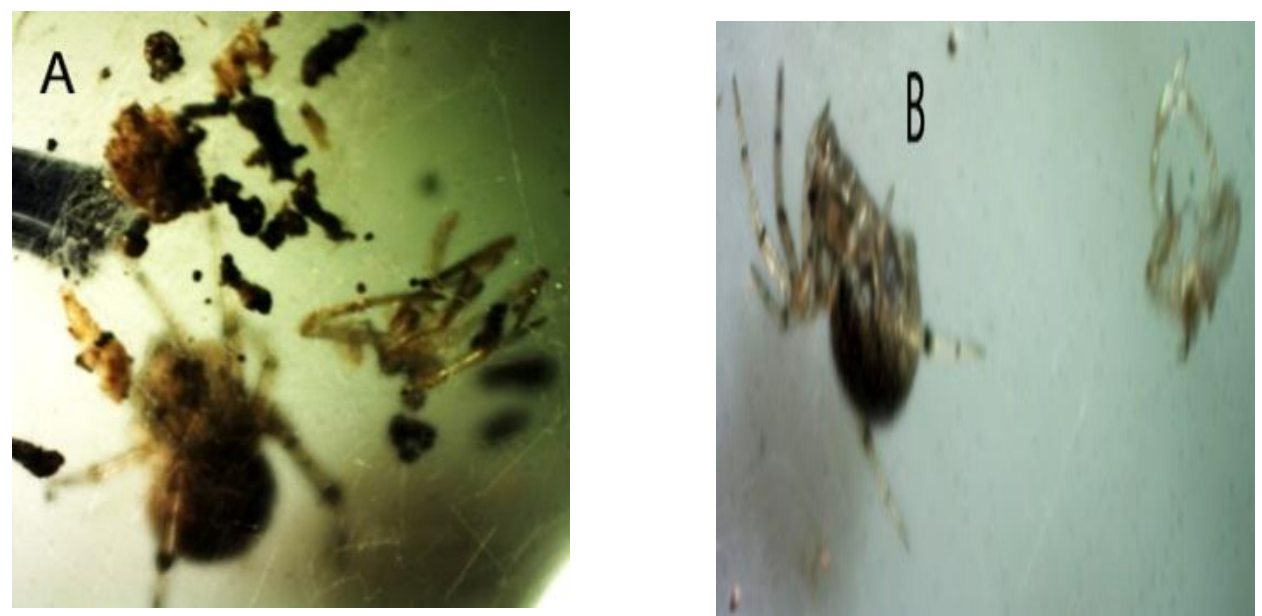

Fig. (3): Theridion spinitarse O. Pickard-Cambridge molting. A (Adult) and B (Immature)

Table (1): Developmental duration (indays) of different stages of Theridion spinitarse 0. Pickard-Cambridge, 1876.

\begin{tabular}{|c|c|c|c|c|c|c|}
\hline \multirow{2}{*}{$\begin{array}{c}\text { Developmental } \\
\text { stage }\end{array}$} & \multicolumn{3}{|c|}{ Male } & \multicolumn{3}{c|}{ Female } \\
\cline { 2 - 7 } & Mean(day) & S.D. & Range & Mean(day) & S.D. & Range \\
\hline Incubation period & 15.00 & 0.00 & 15 & 15.00 & 0.00 & 15 \\
\hline 1st spiderling & 3.00 & 0.00 & 3 & 3.00 & 0.00 & 3 \\
\hline 2nd spiderling & 9.83 & 2.71 & $9-13$ & 9.82 & 2.23 & $9-13$ \\
\hline 3rd spiderling & 12.17 & 2.86 & $11-18$ & 13.64 & 2.94 & $7-18$ \\
\hline 4th spiderling & 12.17 & 1.83 & $11-15$ & 12.55 & 4.59 & $7-25$ \\
\hline 5th spiderling & 14.83 & 1.47 & $12-16$ & 18.27 & 4.61 & $15-28$ \\
\hline Total spiderlings & 52.00 & 1.55 & $50-53$ & 57.27 & 8.15 & $50-76$ \\
\hline Life cycle & 67.00 & 1.55 & $65-68$ & 72.27 & 8.15 & $65-91$ \\
\hline Adult longevity & 93.17 & 2.93 & $88-96$ & 83.00 & 13.78 & $56-98$ \\
\hline Life span & 160.17 & 2.04 & $156-161$ & 155.27 & 8.88 & $139-164$ \\
\hline
\end{tabular}

\section{Developmental duration of female:}

The oviposition period of $T$. Spinitarse was approximately twice the pre-oviposition period, where they were $41.82 \pm 13.25$ and $25.73 \pm 7.25$ days, respectively. Postoviposition period was $15.45 \pm 6.36$ days. During oviposition period, the average number of laid egg sacs by female was3.55 \pm 0.82 . Every one contained 28.8 \pm 8 .3eggs (Table 2).

The obtained results disagree with Rahil (2004) who reported that it may be due to nutrition difference in consumed prey, where the white fly, Bemisia tabaci adults are 
poorer in protein content compared with cotton leaf worm, $S$. littoralis.

\section{Food consumption:}

During the study $T$. spinitarse first and second spiderlings fed on the first instar of $S$. littoralis, while the other instars were fed on the second instar larvae of $S$. littoralis (Table 3).

The number of consumed larvae during various instars increased gradually with increasing individual's instar not with increased numbers of consumed larvae by female in all instars.

The average number of consumed preys during total spiderlings duration was $96.0 \pm$
3.8 and $103.9 \pm 15.2$ larvae by male and female, respectively.

The average number of consumed preys during duration of adult longevity was 247.3 \pm 18.0 and $227.1 \pm 34.1$ larvae by male and female, respectively.

The obtained results showed that the female of $T$. spinitarse consumed prey slightly more than the male during all stages, this may be due to that females needed more amounts of protein for fertility and lay eggs comparing with males, these results are in agreement with Hussein et al. (2003), Abo-Taka et al. (2004), Abd El-Azim (2014), Ahmad \& Abd El- Maaboud (2014) and Sallam, et al. (2015).

Table (2): Developmental duration of Theridion spinitarse female.

\begin{tabular}{|l|c|c|c|}
\hline \multicolumn{1}{|c|}{ Developmental periods } & Mean & S.D. & Range \\
\hline Pre-oviposition period(days) & 25.73 & 7.25 & $13-36$ \\
\hline Oviposition period (days) & 41.82 & 13.25 & $20-65$ \\
\hline Post-oviposition period (days) & 15.45 & 6.36 & $20-65$ \\
\hline Number of eggs/egg sac & 28.8 & 8.3 & $19-43$ \\
\hline Number of egg sacs/female & 3.55 & 0.82 & $2-5$ \\
\hline
\end{tabular}

Table (3): Food consumption of S. littoralis larvae for Theridion spinitarse.

\begin{tabular}{|c|c|c|c|c|c|c|c|c|}
\hline \multirow{2}{*}{$\begin{array}{c}\text { Developmental } \\
\text { Stage }\end{array}$} & \multicolumn{4}{|c|}{ Male } & \multicolumn{4}{c|}{ Female } \\
\cline { 2 - 6 } & \multicolumn{3}{|c|}{ consumed larvae } & \multirow{2}{*}{$\begin{array}{c}\text { Daily } \\
\text { rate }\end{array}$} & \multicolumn{3}{|c|}{ consumed larvae } & \multirow{2}{*}{$\begin{array}{c}\text { Daily } \\
\text { rate }\end{array}$} \\
\cline { 2 - 5 } & Mean & S.D. & Range & & Mean & S.D. & Range & \\
\hline 1st spiderling & 3.3 & 0.8 & $2-4$ & 1.1 & 3.5 & 1.0 & $2-5$ & 1.2 \\
\hline 2ndspiderling & 11.2 & 2.6 & $9-15$ & 1.2 & 11.2 & 1.5 & $9-13$ & 1.2 \\
\hline 3rdspiderling & 16.2 & 2.7 & $11-18$ & 1.4 & 18.6 & 4.7 & $10-27$ & 1.4 \\
\hline 4th spiderling & 29.7 & 4.0 & $25-34$ & 2.4 & 29.8 & 8.0 & $20-52$ & 2.5 \\
\hline 5thspiderling & 35.7 & 3.4 & $30-40$ & 2.4 & 40.7 & 9.5 & $34-68$ & 2.3 \\
\hline Total spiderlings & 96.0 & 3.8 & $90-102$ & 1.8 & 103.9 & 15.2 & $90-147$ & 1.8 \\
\hline Adult longevity & 247.3 & 18.0 & $224-276$ & 2.7 & 227.1 & 34.1 & $154-264$ & 2.8 \\
\hline
\end{tabular}




\section{ACKNOWLEDGMENT}

The authors are indebted to Col. Hisham K. El-Hennawy (Arachnid Collection of Egypt, Cairo) who kindly revised a draft of the manuscript.

\section{REFERENCES}

Abd El-Azim, Nahla A.I. (2014). Rearing Theridion melanostictum O. P. Cambridge (Araneae: Theridiidae) on Tetranychus urticae Koch and larvae of Spodoptera littoralis Boisduval, Acarines , Vol.8(2): 79-82.

Abo-Taka, Safaa M., A. M.Hussein, A. A. Osman, G.I.Zohdi and E.G.I.Hamada (2004). Studies on some biological aspects of Theridion melanostictum O.P.Cambridge, 1876 (Arachnida: Araneida). Serket, 9(1): 5-9.

Ahmad, Naglaa F. R. (2009). Biological, toxicological and mass rearing possibility of the spider Kochiura aulica (C. L. Koch, 1838).Ph.D. Thesis, Fac. Agric., Benha Univ. Egypt. 226pp.

Ahmad, Naglaa. F. R. and A. S. Abd ElMaaboud (2014). Biological aspects ofthe spider,Theridion incanescens (Araneae: Theridiidae) feeding on Tetranychus urticae and Ceratitis capitata with notes on its mating behaviour. Egypt. Acad. J. Biolog. Sci., 7(2): 9 - 14.

Bonnet, P. (1930). La mue, 1'autotomie et la regeneration chez les Araignees, avec une etude des Dolomedes d'Europe. Bull .Soc .Nat .Hist . Toulouse 59:237-700.

El-Hennawy, H. K. (2006). A list of Egyptian spiders (revised in 2006). Serket, 10(2):65-76.

El-Hennawy, H.K. and Ahmad Naglaa. F. $R$. Redescription of Theridion spinitarse O. Pickard-Cambridge, 1876 (Araneae: Theridiidae) from Egypt. Serket, In Press.

Foelix, R.F. (2011). Biology of Spiders.Third Edition. Oxford University.432 pp.

Hussein, A.M., M.F. Hassan and N.F.R. Ahmad (2003). Biological aspects of
Anelosimus aulicus (C.L. Koch, 1838) (Arachnida: Araneida: Theridiidae) in Egypt, Serket, 8(4): 129-134.

Levi, H.W. (1957). The spider genera Enoplognatha, Theridion, and Paidisca in America North of Mexico. (Araneae, Theridiidae). Bulletin of the American Museum of Natural History, 112: 1- 123.

Levi, H.W. (1959). The spider genera Achaearanea, Theridion and Sphyrotinus from Mexico, Central America and the West Indies (Araneae, Theridiidae). Bulletin of the Museum of Comparative Zoology, 121(3):57-163.

Levi, H.W. (1963). American spiders of the genus Theridion (Araneae, Theridiidae). Bull. the Museum of Comparative Zoology, 129(10): 481- 589.

Levy, G. and P. Amitai (1982). The combfooted spider genera Theridion, Achaearanea and Anelosimus of Israel (Araneae: Theridiidae). J. Z., London 196: 81-131.

Liu Hancai, Li Xiao-hong, ChenQian, Wu Zhengchuan.(2002).Biological characters of Theridion octomacutatum and its regularity of outbreak in farmland. Hubei Agricultural Sciences 5:99-102.

Cambridge, O. P. (1876). Catalogue of a collection of spiders made in Egypt, with descriptions of new species and characters of a new genus., Proc. Zool. Soc. Lond. 1876: 541-630.

Platnick, N. I. (2014). The world spider catalog, version 15. American Museum of Natural History, online at: http://research.amnh.org/iz/spiders/catalo g_15.0/index.html

Rahil, A. A. R. (2004). Studies on the biological characteristics of the combfooted spider Theridion spinitarse (Theridiidae) and the crab spider Thanatus fabricii (Philodromidae). Fayoum J. Agric. Res. \& Dev., 18 (1): 163-169.

Sallam, M. E.Gihan, Nahla A.I.Abd El-Azim and H. M.G. El-Kawas (2010). 
Biodiversity of spiders associated with cotton and maize in Sharkia Governorate with a special reference to the spider Kochiura aulica (Koch). Acarines, 4: 6771.

Sallam, Gihan M.E. Nahla A.I.Abd El-Azim and M. A. Mohafez (2015). A study ofsome biological aspects of the spider Theridion jordanense Levy \& Amitai, 1982 (Araneae: Theridiidae) in Egypt. Egypt. Acad. J. Biolog. Sci., 8(1): 73 77.

Thaler-Knoflach, B. and H. K. El-Hennawy (2012). Theridion incanescens

Simon, 1890 and Theridion jordanense Levy \& Amitai, 1982 new to the fauna of Egypt. (Araneae: Theridiidae). Serket, 13(1/2): 91-98.
Thaler-Knoflach, B.,C.Rollardand K.Thaler (2009).Notes on Mediterranean Theridiidae (Araneae) - II.ZooKeys 16:227-264.

Wunderlich, J. (2011). Extant and fossil spiders (Araneae). Beitr. Araneol., 6: 1640.

$\mathrm{Yu}$ Hong-Guo, Wang Chang-gui,Li YiMing,Lu Qing.(2009). Observation on the Biological Characteristics of Theridion tepidariorum Koch. Jiangxi Plant Protection , 2: 87-89.

Zhuang Su-Xue Wang Chang-Gui Chen Dong Yan Feng-Jun CuiFa-Liang (2005). Biological Characteristics of Theridion pinastri. Chinese J. Z., 6:96-98.

Theridion spinitarse Pickard-Cambridge,1876 دراسة الخصائص البيولوجية للعنكبوت في مصر (Araneae:Theridiidae)

(2)

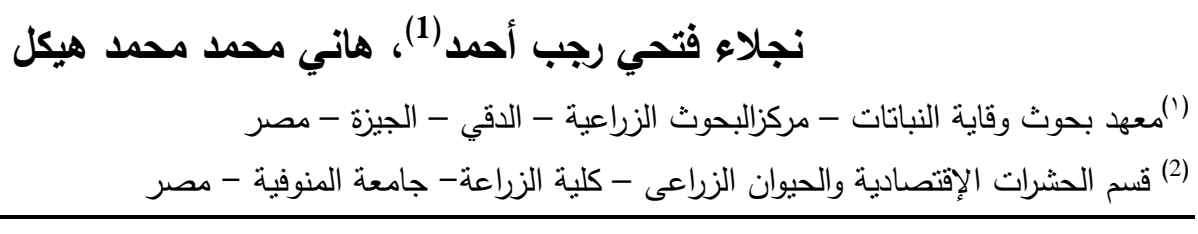

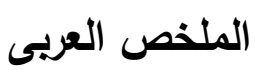

تم وصف الانثي لهذا النوع للمرة الاولي بواسطة O. Pickard-Cambridge, 1876 ثم تم اعادة الوصف بواسطة Knoflach et al., (2009) وتم وصف الذكر للمرة الاولي بواسطة El-Hennawy \& Ahmad (تحت النشر). تم جمع أفراد هذاالنوع من العنكبوت Theridion spinitarse من مزارع المانجو من منطقة ابشواي بمحافظة الفيوم وكذلك من مزارع العنب بمنطقة السادات محافظة المنوفية. تمت التربية ودراسة الخصائص البيولوجية لهذا النوع تحت

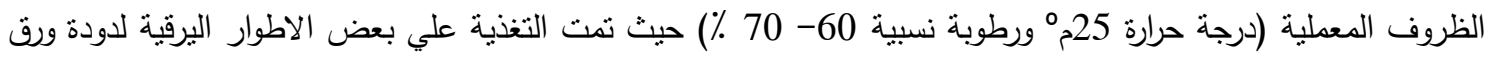
القطن ، وسجلت النتائج أن كل من الذكور والاناث وصلت الي الطور البالغ بعد خمس انسلاخات استغرقت 67 ، 6 ،

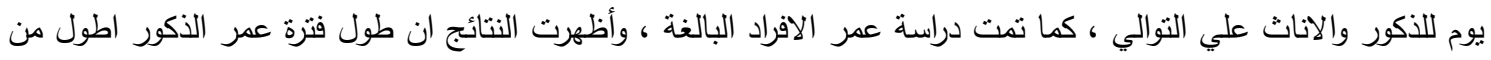
الإناث حيث سجلت 93,17 ، 83,00 يوم على النوالى ، كما نم حساب خصوبة الإناث و حساب عدد الفرائس المستهلكة .

البريد الالكترونى

E-mail: mujareg@gmail.com
موقع المجلة

Mujareg.blogspot.com 
